\title{
ИСТОРИЯ
}

УДК 94(47).084.5; 94(47).084.6

DOI: $10.22162 / 2500-1523-2020-4-752-763$

\section{Партия и СМИ (развитие партийно-советской печати Калмыкии в 20-30-е гг. XX в.)}

\section{Евгения Викторовна Сартикова}

${ }^{1}$ Калмыцкий научный центр РАН (д. 8, ул. И. К. Илишкина, 358000, Элиста, Российская Федерация) доктор исторических наук, доцент, ведущий научный сотрудник (iD) 0000-0003-3472-6435. E-mail: sartikova_evgeniya@mail.ru

(C) КалмНЦ РАН, 2020

(C) Сартикова Е. В., 2020

Аннотация. Введение, На основе анализа архивных источников показан процесс становления и развития партийно-советской печати Калмыкии в 20-30-е гг. XX в. Партийная организация Калмыкии уделяла серьезное внимание развитию средств массовой информации. Если до 1926 г. в Калмыцкой области выходила только одна печатная газета «Улан Хальмг» («Красный калмык»), то с 1926 г. начали издаваться газеты «Красная степь», «Калмыцкие известия», журналы «Вестник Калмыцкого обкома ВКП(б)», «За работу» и др. Источниковедческой основой статьи являются документы партийного фонда Национального архива Республики Калмыкия. Степень достоверности результатов исследования обеспечивается привлечением значительного объёма документальных источников. Анализ архивных материалов осуществлен на таких принципах, как объективность и историзм. Целью данного исследования является анализ деятельности Калмыцкой областной партийной организации в становлении печати Калмыкии. Результаты. Сделан вывод о том, что вопросы развития печати регулярно рассматривались на партийных конференциях, пленумах и заседаниях бюро Калмыцкого обкома партии. Бюро Калмыцкого обкома ВКП(б) укрепляло республиканские и улусные газеты и журналы опытными журналистами. В издаваемых книгах и брошюрах обобщался опыт политической, организационной и идеологической деятельности партийных организаций. Издание газет и журналов на калмыцком и русском языках укрепляло связи партии с народом, облегчало проведение в жизнь своей политики. Печать использовалась партией и партийными организациями как политическое орудие в мобилизации и просвещении трудящихся.

Ключевые слова: Калмыкия, Калмыцкая областная партийная организация, деятельность, руководство, газеты, журналы, Вестник Калмыцкого обкома ВКП(б), идеологическая работа

Благодарность. Исследование проведено в рамках государственной субсидии - проект «Комплексное исследование процессов общественно-политического и культурного развития народов Юга России» (номер госрегистрации АААА-А19-119011490038-5). 


\title{
История
}

Для цитирования: Сартикова Е. В. Партия и СМИ (развитие партийно-советской печати Калмыкии в 20-30-е гг. ХХ в.) // Монголоведение. 2020. Т. 12. № 4. С. 752-763. DOI: $10.22162 / 2500-1523-2020-4-752-763$

UDC 94(47).084.5; 94(47).084.6

DOI: $10.22162 / 2500-1523-2020-4-752-763$

\section{Party and Mass Media: Development of Party-Soviet Print Media in Kalmykia, 1920s-1930s}

\author{
Evgeniya $V$. Sartikova ${ }^{1}$ \\ ${ }^{1}$ Kalmyk Scientific Center of the RAS (8, Ilishkin St., Elista 358000, Russian Federation) \\ Dr. Sc. (History), Associate Professor, Leading Research Associate \\ iD 0000-0003-3472-6435. E-mail: sartikova_evgeniya@mail.ru
}

(C) KalmSC RAS, 2020

(C) Sartikova E. V., 2020

\begin{abstract}
Introduction. The paper provides insight into archival sources and shows the development of Kalmykia's party-Soviet print media during the 1920s and 1930s. Kalmyk Party Organization tended to keep a strong focus on the growth of mass media in the region. So, before 1926 there was only one newspaper in Kalmyk Oblast - Ulan Khal'mg (Kalm. 'Red Kalmyk'), while that very year proper witnessed the emergence of multiple periodicals, such as Krasnaya step' (Russ. 'Red Steppe'), Kalmytskie izvestiya (Russ. 'Kalmyk News'), journals Vestnik Kalmytskogo obkoma VKP(b) (Russ. 'Newsletter of Kalmyk Oblast VKP(b) Committee'), Za rabotu (Russ. 'Down to Work'), etc. Goals. The study seeks to clarify the impacts of Kalmyk Oblast Party Organization on the development of regional print media. Materials and Methods. The article analyzes multiple - and authentic documents stored at the National Archive of Kalmykia (Party Collection), key research principles being those of objectivity and historicism. Results. The work concludes that issues of print media's development were regularly discussed at Party conferences, plenums, and meetings of Kalmyk Oblast Party Committee. The latter's Bureau would employ experienced journalists to strengthen republican and district-level newspapers. The published books and brochures were summarizing political, organizational, and ideological experiences of party organizations. Kalmyk- and Russian-language newspapers and journals were tightening ties between the Party and people, which facilitated an easier implementation of state policies. Thus, print media were used by the Party and its agencies as a means of political mobilization and education.
\end{abstract}

Acknowledgements. The reported study was funded by government subsidy — project name 'Socio-Political and Cultural Development of South Russia's Peoples: Comprehensive Research of Respective Processes' (state reg. no. AAAA-A19-119011490038-5).

For citation: Sartikova E. V. Party and Mass Media: Development of Party-Soviet Print Media in Kalmykia, 1920s-1930s. Mongolian Studies (Elista). 2020. Vol. 12. No. 4. Pp. 752-763. (In Russ.). DOI: 10.22162/2500-1523-2020-4-752-763

В связи со столетием автономии Калмыкии становится актуальной проблематика регионального уровня. Необходимо подчеркнуть, что до сих пор мы не имеем объективной картины становления и развития партийно-советской 


\section{Монголоведение • Mongolian Studies • 2020 ๑ T. 12 • № 4}

печати в Калмыкии. Данная статья призвана хотя бы частично восполнить существующий пробел.

Как только закончилась Гражданская война на территории Калмыцкой степи, после образования Калмыцкой автономной области (1920 г.) большевики приступили к организационному оформлению партийной организации. 12 декабря 1920 г. в Астрахани состоялась уездная партийная конференция, на которой был избран уездком. К работе уездный комитет партии приступил только 1 января 1921 г. Уже тогда перед большевиками стояли задачи по усилению агитационно-пропагандистской работы в области, по созданию своего печатного органа, организации экспедиции для широкого распространения литературы и газет по области [НА РК. Ф. П-1. Оп. 1. Д. 8. Л. 48].

Истории партийно-советской печати Калмыкии не уделялось особого внимания. Начало изучению истории печати в Калмыкии было положено в брошюрах Б. Г. Майорова [Майоров 1967; Майоров 1971], А. Г. Маслова [Маслов 1962] и др., а первым исследователем этой темы стал А. С. Романов [Романов 1971; Романов 1973]. Он осветил работу печати Калмыкии в годы Гражданской войны (разумеется, только большевистской и советской печати), писал об истории создания военной газеты «Улан хальмг» («Красный калмык») и газеты «Трудовой калмык», их роли в событиях Гражданской войны. Автор обращал внимание на движение рабселькоров в улусах, на место печати в реконструкции народного хозяйства, на ее общественно-просветительную работу, характер и содержание журналов: «За работой» (1927), «Калмыцкая степь» (1927-1929), «Мана келн» («Родное слово») (1928-1929). Однако 1930-е гг. в истории печати Калмыкии освещены еще слабо. Определенный материал о развитии печати также содержится в коллективных трудах [Очерки истории 1970; Очерки истории 1980; История Калмыкии 2009].

Продолжила изучение истории печати Б. Б. Санджиева, написав в 1985 г. диссертацию по истории партийно-советской печати [Санджиева 1985]. В исследовании она рассмотрела партийное руководство печатью в деле ликвидации неграмотности и просвещения калмыцкого народа. К истории создания и работы Калмыцкого подотдела печати в Астрахани обратился В. А. Стоянов. Он изучал обстоятельства возникновения Калмыцкого книжного издательства [Стоянов 2009].

Научное изучение истории партийно-советской печати в Калмыкии свидетельствует о том, что комплексных исследований по данной теме недостаточно. Большая их часть написана в советский период, когда многие факты замалчивались, внимание акцентировалось только на положительных результатах становления и развития периодической печати. Можно согласиться с мнением Б. Б. Дякиевой о том, что «во всех исследованиях имеется мало различий: они однообразны по содержанию, основываются на пространственно-временном принципе изучения, отличаются догматизмом, стремлением завысить роль партийных организаций в деле развития прессы» [Дякиева 2017: 17]. Поэтому сегодня необходимо переосмысление данной научной проблемы с деидеологизированной точки зрения и учетом современной методологии.

На первой Областной партийной конференции (1921г.) был избран Областной Комитет РКП(б). Рабочим аппаратом Калмыцкого областного коми- 


\section{История}

тета партии являлся Секретариат, состоявший из нескольких отделов, в том числе агитационно-пропагандистского, который вел работу в области агитации, пропаганды и печати [НА РК. Ф. П-1. Оп. 1. Д. 59. Л. 173]. В области печати отдел руководил областным органом печати, уездной печатью, областным агентством печати. Кроме того, агитационно-пропагандистский отдел организовывал партийные библиотеки, принимал участие в организации изб-читален.

Как показывают архивные материалы, на состоявшейся 17 марта 1923 г. IV областной партийной конференции, издательская работа была вынесена в повестку дня специальным докладом. В нем, в частности, отмечалось, что вся издательская работа в Области сосредотачивалась на двух периодических изданиях: «Вестнике агитации и пропаганды» Обкома партии и газете «Красный калмык». Жизнь Области на страницах этих изданий освещалась недостаточно. Причина этого, как подчеркивалось в докладе, состояла в том, что «большинство ответственных работников Области мало уделяли внимания издательской работе» [НА РК. Ф. П-1. Оп. 1. Д. 40. Л. 35]. Типография в то время имела две машины и два электромотора. Единственный недостаток в её работе - нехватка шрифта. Об этом было сообщено в ЦК РКП(б), но «из-за недостатка средств шрифт заказать не удалось. В типографии работало 3 человека (заведующий и два наборщика (ученики педагогического техникума)» [НА РК. Ф. П-1. Оп. 1. Д. 40. Л. 38].

IV Областная партийная конференция (1923г.), подчеркнув неудовлетворительное состояние областной печати, предложила областному комитету партии и всем ответственным партийным работникам уделять максимум внимания её развитию. Областная газета «Красный калмык» совсем не походила на газету. Выходя нерегулярно (один-два раза в месяц, а иногда и ни разу), она вмещала в себя не более 2-3 статей больших размеров, наполненных массой «варваризмов», совершенно непонятных, в том числе и для улусных работников. Круг читателей «Красного калмыка» ограничивался десятком ответственных работников центра области. К тому же из-за отсутствия средств, в улусы газета отправлялась только с оказией, пролеживая в редакции целыми неделями. Для окончательной характеристики газеты еще следует добавить изобилие орфографических и грамматических ошибок. Подотдел печати агитационно-пропагандистского отдела (далее - Агитпроп) обкома партии после IV партконференции приступил к работе по исправлению указанных недостатков. Прежде всего, была поставлена на должную высоту корректура. В содержании газеты открылись следующие постоянные отделы: «По Советским Республикам», «По Калмыцкой области», «Судебный отдел», «Народное образование», «Кооперация», «Партийная жизнь» и временные отделы: «Помощь воздухофлоту», «Красная Армия», «Профессиональная жизнь», «Сельскохозяйственная выставка».

Кроме этого, периодически появлялась для комсомольцев «Страничка молодежи». В целях освещения на страницах газеты жизни улусов, подотделом печати Агитпропа был принят циркуляр всем улускомам о выделении корреспондентов. Эта мера вскоре дала положительные результаты: «Отдел по Калмобласти» значительно увеличился. Началось печатание газеты на калмыцком языке, когда впервые вышла страничка с калмыцким текстом» [НА РК. Ф. П-1. Оп. 1. Д. 48. Л. 32]. Спустя несколько месяцев на калмыцком языке стала вы- 


\section{Монголоведение • Mongolian Studies • 2020 ๑ T. 12 • № 4}

ходить целая страница. Дальше этого расширить объем калмыцких текстов не удалось. Несмотря на то, что IV партконференция предложила всем ответственным работникам уделять максимум времени областной печати, из всех работников центра Области более или менее постоянно работали в газете 5-6 человек. В течение 1923 г. после IV партконференции газета была бесплатной, находясь на полном содержании типографии, и лишь в конце февраля 1924 г. были предприняты первые шаги к введению платности. С этой целью Агитпроп отдел разработал циркуляр, в котором улускомам предписывалось провести кампанию подписки на газету. Сведений о практических результатах кампании с мест не поступало. Конечно, подписка не давала редакции больших материальных возможностей, она, скорее всего, являлась лишь полуактивной мерой. За 1922-1923 гг. в «Красном Калмыке» были проведены следующие кампании: «25-летие РКП(б)», «Помощь воздухофлоту», «Неделя беспризорного ребенка», «Помощь школе взрослых», «Неделя Красного флота», «Решения XII съезда РКП(б)», «День кооперации», «Шестая годовщина Октябрьской революции», и, наконец, 4 номера были посвящены В. И. Ленину. Всего за 1923 год вышло 36 номеров, за 3 месяца 1924 г. - 12 номеров. Некоторые номера выпускались с увеличенным тиражом до 1000 экземпляров. Всего выпущено 14800 экз. за 1923 г. и 7500 экз. за 3 месяца 1924 г. Газета высылалась в улусы почтой и с командированными работниками [НА РК. Ф. П-1. Оп. 1. Д. 48. Л. 33].

Несмотря на то, что это была военная газета, Областной комитет партии все же обращал внимание на необходимость освещать в газете жизнь улусов. Но, как писали Р. Б. Дякиева и К. Н. Максимов, «газета играла огромную роль в мобилизации, политическом воспитании бойцов и командиров 1-го Калмыцкого кавалерийского полка» [Дякиева, Максимов 2009: 529].

Кроме газеты «Красный калмык», Агитотделом Калмыцкого обкома партии издавался ежемесячный журнал «Вестник Калмыцкого обкома РКП(б)» (1922-1926) тиражом 350 экземпляров, предназначенный для низового партийного актива. С «Вестником» дело обстояло благополучно. Выходил он аккуратно, и тираж его вполне был достаточен для сравнительно малочисленной тогда партийной организации. К недостаткам «Вестника», как указывалось в докладе на IV Областной партийной конференции, относились, во-первых, плохое освещение экономических вопросов Калмыцкой области; во-вторых, неважное литературное качество; в-третьих, небольшое число лиц, работавших в журнале, и, в-четвертых, выход «Вестника» на русском языке.

Исследование источников показало, что за 1922-1923 гг. вышло 13 номеров «Вестника Калмыцкого обкома РКП(б)» или 4550 экземпляров. В целях распространения среди калмыцкого населения сведений об экономической и национальной политике власти, агитационно-пропагандистским отделом Обкома партии были выпущены следующие брошюры: «Какое дело русскому крестьянину до Германской революции» (500 экземпляров) и «Революции ЦК и ЦКК по внутрипартийному и экономическому вопросам» (350 экз.). В переводе находилась «Книга политграмоты» Коваленко [НА РК. Ф. П-1. Оп. 1. Д. 48. Л. 33]. С № 7-8 «Вестник» включал постоянные отделы: общий, о Ленине, Калмпросвещение, работа на местах, работа Обкома партии, самообразование - спутник агитатора, профессиональная жизнь, наше хозяйство, вопросы быта, на трудовом фронте, наша смена, политобозрение и официаль- 


\section{История}

ный отдел [НА РК. Ф. П-1. Оп. 1. Д. 59. Л. 66]. Журнал «Вестник Калмыцкого обкома РКП(б)» содержал много информации о работе улусных комитетов партии, о состоянии партийной работы в области. Он широко освещал вопросы партийного просвещения кадров, деятельность различных общественных организаций. В журнале публиковались материалы партийных конференций, пленумов, протоколы заседаний бюро Калмыцкого обкома партии, циркулярные письма обкома улусным комитетам партии, систематически помещались отчеты о работе областной совпартшколы, сведения о подготовке кадров партийных кадров.

Необходимо отметить, что вопросы развития печати и издательского дела регулярно рассматривались на партийных конференциях и заседаниях бюро Калмыцкого обкома партии. Так, на V областной партийной конференции (апрель 1924 г.) отмечалось, что «работа в области печати во многом тормозилась особенностью калмыцкой письменности. Обком партии поручил ЦИКу Области изучить вопрос о письменности и в случае необходимости провести её реформу» [НА РК. Ф. П-1. ОП. 1. Д. 48. Л. 4].

В отчете ОК РКП(б) в ЦК РКП(б) за 1924 г. подчеркивалось, что центральное место в работе подотдела печати занимал вопрос о переходе к русской транскрипции, которая должна была заменить собой зая-пандитский алфавит [НА РК. Ф. П-1. Оп. 1. Д. 59. Л. 25]. Старокалмыцкая, так называемая зая-пандитская письменность находилась в употреблении до 1924 г. В декабре 1923 г. заведующий областным отделом образования Х. Косиев, вернувшись из командировки в Наркомпрос, обратился в Президиум Калмыцкого ЦИК с просьбой о созыве совещания, посвященного языковой проблеме. 6 января 1924 г. участники собрания калмыцкой общественности решили создать новую калмыцкую письменность на русской графической основе. С начала 1926 г. в Калмыкии повсеместно был введен в употребление алфавит на основе русской графики. Калмыки пользовались русским алфавитом с дополнительными латинскими знаками до 1930 г., после чего был введен латинский алфавит [Сартикова 2008: 121].

Прежде чем областной комитет партии и Калмыцкий облисполком утвердили новый алфавит, он был подвергнут всестороннему исследованию рядом научных и общественных организаций и получил соответствующее одобрение научного Совета Всесоюзного Центрального комитета Ново-тюркского алфавита.

В самой Калмыкии проблема языка и письменности обсуждалась ещё не раз. Основными этапами развития калмыцкой письменности стали: зая-пандитская (1648-1924), русская графика с введением дополнительных знаков (1924-1930), латинский алфавит с дополнительными знаками (1930-1938) и вновь принятие русского алфавита (1938). «В 1920-е годы старокалмыцкая письменность (тодо бичиг) считалась сложной для усвоения, технически неудобной из-за вертикального написания, чем в принципе и объясняется активная агитация за замену её русской транскрипцией», - писал знаток «ясного письма» А. В. Бадмаев [Бадмаев 1992].

Бюро Калмыцкого обкома партии своим постановлением подтвердило необходимость перехода к русской транскрипции. Материалы были переданы в агитпропотдел ЦК РКП(б), которым переход к русской транскрипции также 


\section{Монголоведение • Mongolian Studies • 2020 ๑ T. 12 • № 4}

был санкционирован. С этой целью Калмобком ходатайствовал перед Отделом Печати ЦК партии об изготовлении шрифта русской транскрипции с дополнительными знаками через «Восточное издательство» [НА РК. Ф. П-1. Оп. 1. Д. 59. Л. 25].

Партийной организации приходилось решать многие организационные и хозяйственные вопросы, связанные с дальнейшим укреплением печати.

В 1926 г. по решению бюро обкома партии газета «Улан хальмг» переименовывается в газету «Красная степь». Разноплановая по тематике, выступавшая по самым насущным вопросам своего времени, газета ставила и освещала вопросы народного образования, доходчиво объясняла трудящимся острую необходимость просвещения. Материалы всех отделов иллюстрировались рисунками, фотографиями, карикатурами. В разное время газету редактировали партийные и общественные деятели, известные литераторы. В 1926-1927 гг. редактором работал А. Д. Загорянский, его заместителем был молодой писатель Нимгир Манджиев. В дальнейшем коллективом газеты руководили Бадма Майоров (1927-1928), Араши Чапчаев (1928), Улан Илишкин (1930) [Дякиева, Максимов 2009: 530].

Особое внимание «Красная степь» обращала внимание на просветительскую работу среди калмычек: разъясняла равенство прав женщин с мужчинами, выступала за распространение книг и газет среди женщин. Редакция готовила специальные рубрики: «Страницы женщин», «Странички работницы». Для того чтобы газета доходила до рядового читателя, редакция объявила по области подписку на «Красную степь», которой занимались местные уполномоченные по ее распространению. Кроме того, для улусов выписывался журнал «Коммунистка», к 8 Марта 1925 г. был издан первый номер журнала «Первый шаг». Несмотря на трудность проведения работы среди женщин, по Калмобласти насчитывалось около 800 женщин-делегаток, из них 10 чел. в аймисполкомах, одна женщина - в ЦИКе, 2 - в Облпрофсовете, 4 - в Губотделе Союза, 17 - в кооперативных организациях [НА РК. Ф. П-1. Оп. 1. Д. 75. Л. 167].

На VIII Калмыцкой областной партийной конференции (15-20 ноября 1926 г.) отмечалось, что «газета „Красная Степье начала находить массового читателя. Значительно увеличился тираж газеты, который составлял 3000 экземпляров, тогда как до этого было только около 700 экз. бесплатного тиража» [НА РК. Ф. П-1. Оп. 1. Д. 127. Л. 30об.]. А А. С. Романов отмечал, что «усилиями партийных организаций удалось за короткий срок создать материально-техническую базу для областной газеты и подготовить кадры полиграфистов. На этой основе „Красная степь“стала выходить не один раз в неделю, как это было на первых порах, а два раза» [Романов 1969: 37].

Важнейшим в газете был отдел партийной жизни. Здесь публиковались официальные партийные документы, широко освещалась работа съездов, конференций. Отдел партийной жизни выдвигал актуальные вопросы для широкого обсуждения. Делалось это накануне партконференций под рубрикой «Ставим на повестку партконференции». «Подобная практика позволяла коммунистам обратить внимание на нерешенные вопросы. Так, благодаря усилиям областной парторганизации в Калмыкии расширилась сеть политпросвеще- 


\section{История}

ния. Кроме того, со страниц «Красной степи» не сходили вопросы внутрипартийной работы (прием в партию, воспитание молодых коммунистов, укрепление парторганизаций). Материалы публиковались под рубрикой «В ленинских рядах», «В рядах партии» [Романов 1969: 44].

В соответствии с решением II Пленума Калмыцкого обкома ВКП(б) в ноябре 1926 г. стало выходить на калмыцком языке приложение к газете «Красная степь» под названием «Тангчин зянг» («Областные известия»). В июне 1927 г. V Пленум Калмыцкого обкома ВКП(б) признал целесообразным укрупнение газеты на калмыцком языке «Тангчин зянг» с расчетом, чтобы к 1 января 1928 г. она стала основной газетой, а «Красная степь» - приложением [Очерки истории 1980: 121].

В 1927 г. агитационно-пропагандистским отделом Калмыцкого обкома партии недолго издавался и журнал «За работой». На его страницах освещались вопросы партийного жизни, развития экономики, культуры и просвещения Калмыцкой автономной области.

Важную роль в идеологической работе выполняли журналы «Калмыцкая степь» - орган Калмыцкого обкома ВКП(б), облисполкома и облпрофсовета (1927-1929 гг.), «Калмыцкая область» — орган плановой комиссии Калмыцкого облисполкома (1925-1927 гг.), «Мана келн» («Родное слово») - ежемесячный литературно-художественный журнал - орган Калмыцкой ассоциации пролетарских писателей (КАПП). По мнению Т. Ю. Красовицкой, «средства массовой информации настраивали значительные контингенты людей на восприятие партийных установок» [Красовицкая 2014: 216]. Учитывая потребности населения области, Калмыцкий обком ВКП(б) и облисполком начали выпуск молодежной газеты «Теегин герл» («Свет в степи»), первый номер которой вышел 4 января 1929 г. В декабре 1929 г. «Теегин герл» была переименована в газету «Улан бахчуд» (1929-1941). С 1 августа 1930 г. начала выходить газета «Ленинский путь» (1930-1941).

Издание газет и журналов на калмыцком и русском языках укрепляло связи партии с трудящимися, облегчало проведение в жизнь политики Коммунистической партии. Печать использовалась партией и её партийными организациями как политическое орудие в мобилизации и просвещении трудящихся. Как писал профессор К. Н. Максимов, «печатные издания преподносились партийными органами как обретение калмыцким народом голоса, как значительный шаг в его культурном развитии» [Максимов 2002: 281].

Как свидетельствуют архивные источники, к середине 1930-х гг. в республике издавалось 4 республиканские газеты, 7 улусных, 7 политотдельских газет. В отчете обкома партии в ЦК ВКП(б) в 1936 г. отмечалось, что «очень плохо обстояло дело с кадрами газетных работников. Нет редакторов в 3-х улусных и 4 политотдельских газетах. Для подготовки работников редакции улусных газет проводились месячные курсы на 10 чел., 2 республиканских совещания редакторов газет. Содержание газет продолжает оставаться на низком уровне. Большинство улусных и политотдельских газет выпускается с большим количеством грамматических ошибок, а также имеют место и грубые политические ошибки» [НА РК. Ф. П-1. Оп. 1. Д. 249. Л. 53].

Бюро обкома ВКП(б) неоднократно на своих заседаниях обсуждало вопросы деятельности республиканских и улусных газет, укрепляло их опытными 


\section{Монголоведение • Mongolian Studies • 2020 ๑. 12 • № 4}

журналистами. Если раньше на 2 газеты органа Калмыцкого обкома ВКП(б) «Ленинский путь» и «Улан Хальмг» - был один редактор, то в конце 1937 г. были организованы самостоятельные редакционные коллегии газет «Ленинский путь», «Улан хальмг» [НА РК. Ф. П-1. Оп. 3. Д. 6. Л. 90].

В 1939 г. в республике было организовано еще 6 новых улусных газет. Всего издавалось 4 республиканские, 13 улусных газет и 6 газет политотделов. Было проведено 5 областных совещаний редакторов республиканских, улусных и газет политотделов. На бюро обкома заслушивались отчеты редакторов 4 улусных газет и 1 газеты политотдела. Кроме этого, на бюро обкома партии 21 раз обсуждались отдельные вопросы работы газет, 15 раз - вопросы издательства. Было проведено республиканское совещание рабселькоров [НА РК. Ф. П-1. Оп. 3. Д. 342. Л. 21].

В отчетном докладе секретаря обкома ВКП(б) на XVII Областной партийной конференции (1940 г.) отмечалось, что «республиканские и улусные газеты значительно лучше стали работать. Содержательней освещались материалы партийной жизни, улучшилась борьба за успешное решение задач, стоящих перед республикой. Малодербетовская улусная газета „Большевике в 1939 г. за свою хорошую работу была представлена на Всесоюзной сельскохозяйственной выставке и занесена в книгу Почета. 5 газетных работников в 1939 г. прошли практику при редакции газеты „Сталинградская правда“»» [НА РК. Ф. П-1. Оп. 3. Д. 342. Л. 21].

В этот период выделяется своеобразный тип изданий - буквари-газеты, журналы-учебники. Их выпуск стал одной из наиболее приемлемых форм в работе по просвещению населения. Ученые Б. Б. Дякиева и К. Н. Максимов писали, что «в то время, когда в школах не было достаточного количества специальных учебников, наглядных пособий, литературы на родном языке, эти небольшие издания стали значительным подспорьем» [Дякиева, Максимов 2009: 533]. Из газет и журналов, начиная с 1924 г., профсоюз работников просвещения Калмыкии выписывал только «Работника просвещения» и «На путях новой школы» [Сартикова 2014: 25]. В то же время не следует преувеличивать роль периодической печати, потому что в стране, как справедливо указывал исследователь Л. А. Обухов, «где большая часть населения являлась неграмотной, огромную роль играла устная агитация» [Обухов 2017: 25]. Однако в годы первой пятилетки (1928-1932) и в особенности в ходе культштурма периодическая печать получила широкое развитие. Это позволило поднять уровень элементарной культуры взрослого населения [Сартикова 1995: 22].

Процесс становления и развития партийно-советской печати в Калмыкии в 20-30-е гг. XX в. был сложным. Отсутствие подготовленных кадров, технические трудности, слабая типографская база затрудняли работу по развитию партийно-советской печати. Но следует отметить, что в целом газеты и журналы способствовали развитию культуры и просвещения в Калмыкии, становлению национальной литературы и искусства.

Таким образом, как показывает анализ использованных источников, Калмыцкая партийная организация уделяла серьезное внимание развитию средств массовой информации. Вопросы развития печати и издательского дела регулярно рассматривались на партийных конференциях, пленумах и заседаниях 


\section{История}

бюро Калмыцкого обкома партии. Бюро Калмыцкого обкома ВКП(б) укрепляло республиканские и улусные газеты и журналы опытными журналистами. В издаваемых книгах и брошюрах обобщался опыт политической, организационной и идеологической деятельности партийных организаций. Газеты и журналы не только несли передовую культуру, но и вовлекали трудящихся в «строительство новой жизни», укрепляли дружбу калмыцкого народа с русским и другими народами. «Не отрицая положительного значения периодических изданий в жизни калмыцкого народа, все же следует заметить, что на самом деле они являлись идеологическим, пропагандистским оружием партии» [Максимов 2002: 281], а «расчет высшего партийного руководства был направлен на создание абсолютно послушной и управляемой страны» [Красовицкая 2014: 217].

\section{Источники и литература}

НА РК - Национальный архив Республики Калмыкия.

Бадмаев 1992 - Бадмаев А. В. Ойратское «ясное письмо» и его создатель // Известия Калмыкии. 1992. 1 сентября.

Дякиева 2017 - Дякиева Б. Б. Историография печати Калмыкии: этапы и особенности изучения // Вестник Калмыцкого государственного университета. 2017. № 36 (4). С. $12-17$.

Дякиева, Максимов 2009 - Дякиева Б. Б., Максимов К. Н. Печать // История Калмыкии с древнейших времен до наших дней. Т. 3. Элиста: Изд. дом «Герел», 2009. С. $528-538$.

История Калмыкии 2009 - История Калмыкии с древнейших времен до наших дней. Элиста: Изд. дом «Герел», 2009. Т. 3. 752 с.

Красовицкая 2014 - Красовицкая Т. Ю. Партия советских коммунистов. Гл. 2. // История Коммунистической партии Советского Союза. М.: Политическая энциклопедия, 2014. С. 204-235.

Майоров 1967 - Майоров Б. Г. Печать Калмыкии к Х годовщине Октября. Астрахань: Обл. изд-во, 1967.34 с.

Майоров 1971 - Майоров Б. Г. Великая перемена. Элиста: Калм. кн. изд-во, 1971. 72 с. Максимов 2002 - Максимов К. Н. Калмыкия в национальной политике, системе власти и управления России (XVII-XX вв.). М.: Наука, 2002. 524 с.

Маслов 1962 - Маслов А. Г. Страницы былого. Элиста: Калм. кн. изд-во, 1962. 156 с.

Обухов 2017 - Обухов Л. А. Периодическая печать как источник по истории революции 1927 года // Вестник Пермского университета. Серия История. 2017. № 2 (37). C. $17-26$.

Очерки истории 1970 - Очерки истории Калмыцкой АССР. Эпоха социализма. М.: Наука, 1970. 432 с.

Очерки истории 1980 - Очерки истории Калмыцкой организации КПСС. Элиста: Калм. кн. изд-во, 1980. 451 с.

Романов 1969 - Романов А. С. Газета «Калмыцкая степь» (Из истории развития партийно-советской печати Калмыкии) // Вестник института. Серия историко-партийная. Элиста: КНИИ ЯЛИ, 1969. № 4. С. 35-46.

Романов 1971 - Романов А. С. Печать Калмыкии 20-х годов: Очерк. Элиста: Калм. кн. изд-во, 1971. $196 \mathrm{c.}$

Романов 1973 - Романов А. С. Роль партийно-советской печати Калмыкии в борьбе за защиту Советской власти, восстановление и развитие народного хозяйства (1918-1929 гг.): автореф. дис. ... канд ист. наук. Ростов н/Д, 1973. 21 с. 


\section{Монголоведение • Mongolian Studies • 2020 ๑ T. 12 • № 4}

Санджиева 1985 - Санджиева Б. Б. Роль местной партийно-советской печати в осуществлении культурной революции в Калмыкии (1926-1932): дис. ... канд. ист. наук. Ленинград, 1985. 229 с.

Сартикова 1995 - Сартикова E. B. Роль народного образования в создании условий преодоления культурной отсталости калмыцкого народа (с начала XX в. до Второй мировой войны): автореф. дис. ... канд. ист. наук. М., 1995. 25 с.

Сартикова 2008 - Сартикова E. В. Развитие школьного образования в Калмыкии в ХХ веке. Элиста: ЗАОр «НПП «Джангар», 2008. 407 с.

Сартикова 2014 - Сартикова E. B. Становление и развитие профсоюза работников просвещения в Калмыкии: 1921-1928 гг. // Вестник Калмыцкого института гуманитарных исследований РАН. 2014. № 1. С. 23-26.

Стоянов 2009 - Стоянов В. А. Развитие печати Калмыкии в ХХ веке. Элиста: ЗАОр «АПП „Джангар"є), 2009. 413 с.

\section{References and Sources}

National Archive of the Republic of Kalmykia. (In Russ.)

Badmaev A. V. Oirat 'Clear Script' and its creator. Izvestiya Kalmykii. 1992, September 1. (In Russ.)

Chugaev D. A. (ed.) Kalmyk ASSR: Historical Essays. Socialist Era. Moscow: Nauka, 1970. 432 p. (In Russ.)

Dyakieva B. B. The history of the newspaper printing in Kalmykia: periods of time and features of study. Bulletin of Kalmyk University. 2017. No. 36 (4). Pp. 12-17. (In Russ.)

Dyakieva B. B., Maksimov K. N. Print media. In: Maksimov K. N., Ochirova N. G. (eds.) History of Kalmykia: Since Earliest Times to the Present Days. Vol. 3. Elista: Gerel, 2009. Pp. 528-538. (In Russ.)

Gorodovikov B. B. (ed.) Kalmyk Organization of the CPSU: Historical Essays. A. Naberukhin, B. Gorodovikov et al. Elista: Kalmyk Book Publ., 1980. 451 p. (In Russ.)

Krasovitskaya T. Yu. The Party of Soviet Communists (Chapter 2). In: Bezborodov A. V., Yeliseeva N. V. (eds.) Communist Party of the Soviet Union: A History. Moscow: ROSSPEN, 2014. Pp. 204-235. (In Russ.)

Maksimov K. N. Kalmykia in Russia's Past and Present National Policies and Administrative System: $17^{\text {th }}$ to $20^{\text {th }}$ Centuries. Moscow: Nauka, 2002. 524 p. (In Russ.)

Maksimov K. N., Ochirova N. G. (eds.) History of Kalmykia: Since Earliest Times to the Present Days. Vol. 3. Elista: Gerel, 2009. 752 p. (In Russ.)

Maslov A. G. Pages of the Past. Elista: Kalmyk Book Publ., 1962. 156 p. (In Russ.)

Mayorov B. G. Print Media of Kalmykia: Celebrating the $10^{\text {th }}$ Anniversary of the Great October. Astrakhan: Astrakhan Oblast Publ. House, 1927. 34 p. (In Russ.)

Mayorov B. G. The Great Transformation. Elista: Kalmyk Book Publ., 1971. 72 p. (In Russ.)

Obukhov L. A. Periodicals as a source on the history of the 1917. Perm University Herald. History. 2017. No. 2 (37). Pp. 17-26. (In Russ.) DOI: 10.17072/2219-3111-2017-2-1726

Romanov A. S. Kalmykia’s print media in the 1920s: An Essay. Elista: Kalmyk Book Publ., 1971. 196 p. (In Russ.)

Romanov A. S. Kalmytskaya step newspaper: historical development of Kalmykia's partySoviet print media. In: Newsletter of the Kalmyk Research Institute of Language, Literature and History. Ser.: History of the Communist Party. Elista: Kalmyk Research Institute of Language, Literature and History, 1969. Vol. 4. Pp. 35-46. (In Russ.)

Romanov A. S. Struggling for the Soviets, Revival and Development of National Economy: The Role of Kalmykia's Party-Soviet Print Media, 1918-1929. Cand. Sc. (history) thesis abstract. Rostov-on-Don, 1973. 21 p. (In Russ.) 


\section{История}

Sandzhieva B. B. Cultural Revolution in Kalmykia, 1926-1932: The Role of Local PartySoviet Print Media. Cand.Sc. (history) thesis. Leningrad, 1985. 229 p. (In Russ.)

Sartikova E. V. Development of Kalmykia's School Education System: $20^{\text {th }}$ Century. Elista: Dzhangar, 2008. 407 p. (In Russ.)

Sartikova E. V. Establishing Conditions to Overcome the Kalmyk People's Cultural Backwardness (Early $20^{\text {th }}$ Century to WWII): The Role of Public Education. Cand.Sc. (history) thesis abstract. Moscow, 1995. 25 p. (In Russ.)

Sartikova E. V. Formation and development of Trade Union of Workers of Education in Kalmykia: 1920-1928. Bulletin of the Kalmyk Institute for Humanities of the RAS (Oriental Studies). 2014. No. 1. Pp. 23-26. (In Russ.) DOI: 10.22162/2075-7794-201415-1-23-26

Stoyanov V. A. Development of Kalmykia's Print Media: 20 ${ }^{\text {th }}$ Century. Elista: Dzhangar, 2009. 413 p. (In Russ.) 